\title{
Distribution of heavy metals in the core sediments of a tropical wetland system
}

\author{
*P. S. Harikumar; U. P. Nasir; M. P. Mujeebu Rahman \\ Central Water Analysis Laboratory, Centre for Water Resources Development and Management, Kunnamangalam, \\ Kozhikode-673571, Kerala, India
}

\begin{abstract}
Received 25 November 2008; $\quad$ revised 16 January 2009; accepted 18 February 2009; available online 1 March 2009
ABSTRACT: Five sediment cores from the fresh water region of the Vembanad wetland system were studied for the trace element contents The average concentration of iron, manganese, nickel, copper, zinc, cadmium, lead, mercury and chromium were determined. The core samples were collected using gravity type corer, digested with a mixture of nitric acid and perchloric acid and analyzed by atomic absorption spectrophotometry. Heavy metals such as iron, copper, nickel and zinc reported enrichment towards the surface of the core sediment sample collected from the centre of the lake. Lead, cadmium and mercury showed uniform distribution through out the core. Quality of the sediments were evaluated based on sediment quality guidelines, pollution load index, sum of toxic units and with effect range low/effect range median and threshold effect level/probable effect level values of Environmental Protection Agency guidelines. The degree of contamination for each station was determined. The concentration of different heavy metals has been compared with the world average concentration of shale values. Results of the analysis showed that Vembanad lake is facing serious metal pollution with increased rate of deposition.
\end{abstract}

Keywords: Trace elements, lake sediments, sediment quality guidelines, pollution load index, shale values

\section{INTRODUCTION}

Sediments effectively sequester hydrophobic chemical pollutants entering water bodies such as lakes. Lake sediments provide a useful archive of information on changing lacustrine and watershed ecology (Cohen, 2003). Sediments can be sensitive indicators for monitoring contaminants in aquatic environments. The sediments were polluted with various kinds of hazardous and toxic substances, including heavy metals. These accumulate in sediments via several pathways, including disposal of liquid effluents, terrestrial runoff and leachate carrying chemicals originating from numerous urban, industrial and agricultural activities, as well as atmospheric deposition. Core sediments provide useful information on the changes in the quality of the lake from a past period. Many researchers had studied the pollution history of aquatic ecosystem by core sediments (Karbassi et al., 2005; Lopez and Lluch, 2000; Mohamed, 2005). Many researchers have used sediment cores to study the behavior of metals (Bellucci et al., 2003; Bertolotto et al., 2003; Borretzen and Salbu, 2002; Lee and Cundy, 2001; Weis et al., 2001). Sediment core

*Corresponding Author Email: drpshari@yahoo.co.in Tel.: +495 235 1871; Fax: +4952351808 contain information about the events that occurred in precultural time in the lakes and its catchments area. The sediment history broadly reflects the contamination history of an area. Currently, environmental pollution because of urbanization and industrial development is a major concern (Alemdaroglu et al., 2003; Heyvaert et al., 2000; Sadiq, 1992). Concentration of trace metals in coastal estuaries can be elevated due to high inputs from natural, as well as anthropogenic sources. Thus, understanding the transport and distribution of trace metals in estuaries is a goal of environmental chemists (Unnikrishnan and Nair, 2004). One of the most distinguishing features of metals from other toxic pollutants is that, they are not biodegradable. Sediments can incorporate and accumulate many metals added to a body of natural water. The favorable physic-chemical conditions of the sediment can remobilize and release the metals to the water column. It has been stated that specific local sources such as discharge from smelters $(\mathrm{Cu}, \mathrm{Pb}, \mathrm{Ni}$ ), metal based industries (e. g. $\mathrm{Zn}, \mathrm{Cr}$ and $\mathrm{Cd}$ from electroplating), paint and dye formulators ( $\mathrm{Cd}, \mathrm{Cr}$, $\mathrm{Cu}, \mathrm{Pb}, \mathrm{Hg}$, Se and $\mathrm{Zn}$ ), petroleum refineries (AS, $\mathrm{Pb}$ ), as well as effluents from chemical manufacturing plants 
may lead to metal accumulation in sediments (Al-Masri et al., 2002; Bonnevie et al., 1994). In fact, there is a need of controlling both point and non-point discharges and especially pollution prevention by controlling at source discharges of heavy metals from industries (Bakan and Ozkoc, 2007). The Vembanad wetland system is facing many problems, which include pollution due to industrial, agricultural and domestic effluents. The industries release nearly 260 million $\mathrm{L}$ of effluents to the wetland system. Sixteen major industries around Cochin, discharges nearly $0.104 \mathrm{M} \mathrm{m} \mathrm{m}^{3} / \mathrm{d}$ of waste containing organic load into the nearby backwaters (Balachandran et al., 2002). The Cochin estuarine system receives effluents containing a large dose of heavy metals (Ouseph, 1987). Geochemical fractions such as Fe, Co, $\mathrm{Cr}, \mathrm{Cu}, \mathrm{Mn}, \mathrm{Ni}, \mathrm{Pd}$ and $\mathrm{Zn}$ were detected in the coastal sediments of central south-west coast of India, in and around Cochin, the second biggest city along the west coast of India (Balachandran et al., 2003). Concentration of dissolved and particulate trace metals and their partitioning behavior between the dissolved and particulate phases in southern upstream part of the Cochin estuarine system were studied (Unnikrishnan and Nair, 2004). They had presented a seasonal analysis of particulate trace metals, viz. iron, manganese, zinc, copper, cobalt and nickel in Cochin backwaters. The special trend for cobalt, iron and nickel was stationary at surface whereas the metals copper, zinc and manganese showed special variations (Sankaranarayanan et al., 1998). Pillai and Valsala (1995) had studied the seasonal variation of some heavy metals in bivalve mollusk from the Cochin backwaters. Venugopal et al. (1982) studied the trace metal levels in the sediments of the Cochin backwaters and found seasonal changes in the concentration. Postdepositional remobilization of transition metals in deepsea sediment cores from the Pacific, Atlantic and Indian oceans was reported (Mudholkar et al., 1993). This paper presents the environmental quality assessment of five sediment cores of $40-50 \mathrm{~cm}$ length from the fresh water region of Vembanad lake through their geochemical and toxicological study. The main goal of this work is to determine the chronological distribution of trace elements along the core, assess the quality of sediment using different sediment quality guidelines (SQGs), ecological risk assessment, finding the degree of contamination and to correlate the toxicity distribution with chemical concentration in sediment profiles in order to obtain a global picture of the historic sediment quality of the Vembanad wetland system. This study was carried out during a period of six months from January to July 2007.

\section{MATERIALS AND METHODS}

Vembanad Lake (Latitude $9^{\circ} 30^{\prime}$ and $10^{\circ} 12^{\prime}$; Longitude $76^{\circ} 10^{\prime}$ and $76^{\circ} 29^{\prime}$ ) extending from Alleppey in the south to Munambam in the north, is the largest estuarine ecosystem in Kerala, India.The lake has a freshwater dominant southern zone and a salt-water dominant northern zone, both separated by a bund at Thanneermukkom where the lake has its minimum width. Since the entire Cochin estuary is a part of the Vembanad-Kol wetland system, the pollutants from the industrial area of Cochin are transferring towards the fresh water region of the Vembanad Lake (Harikumar et al., 2007). The area under investigation includes the fresh water dominant southern zone, which is facing innumerable problems, including flooding, salinity intrusion, water quality deterioration, weed infestation, etc. This upstream part of Vembanad wetland system is characterized by a vast area of low lying highly fertile agricultural lands, which is below the mean sea level. Tidal flushing of the backwater system does not take place in summer season due to the closure of Thanneermukkom bund, which had been constructed to prevent the intrusion of salinity into the paddy fields. This results in the accumulation of toxic contaminants like heavy metals in the sediments of the lake. The core samples of sediments were collected using gravity type sediment corer of $0.5 \mathrm{~m}$ length. The sampling stations include areas near the urban and domestic effluent discharge points, agricultural dewatering areas and places of tourism activities. The sediment cores have been cutted into slices of approximately 2-4 cm length and labeled. Fig. 1 shows the details of sampling stations. The core $3 / \mathrm{V}$ are sliced into 9 pieces, $7 / \mathrm{V}$ into 12 pieces, $\mathrm{C} / \mathrm{V}$ into 19 pieces, 15/V into12 pieces and 18/V into 12 pieces. The samples (each slices of the core) were brought to the laboratory using ice bags and stored in a deep freeze unit until the drying procedure (UNEP, 1985). For the digestion of the sediment sample, one gram of dried and homogenized sediment samples was weighed and placed in to an acid washed PTFE digestion vessel. The digestion was performed with a mixture $\mathrm{HNO}_{3}$ and $\mathrm{HClO}_{4}$ acid. The digested samples were analyzed for heavy metals by Thermo M5 series AAS (USEPA, 1999).

\section{RESULTS AND DISCUSSION}

Variation of heavy metal along the core

The concentration of iron varied from $25.55 \mathrm{~g} / \mathrm{kg}$ to 


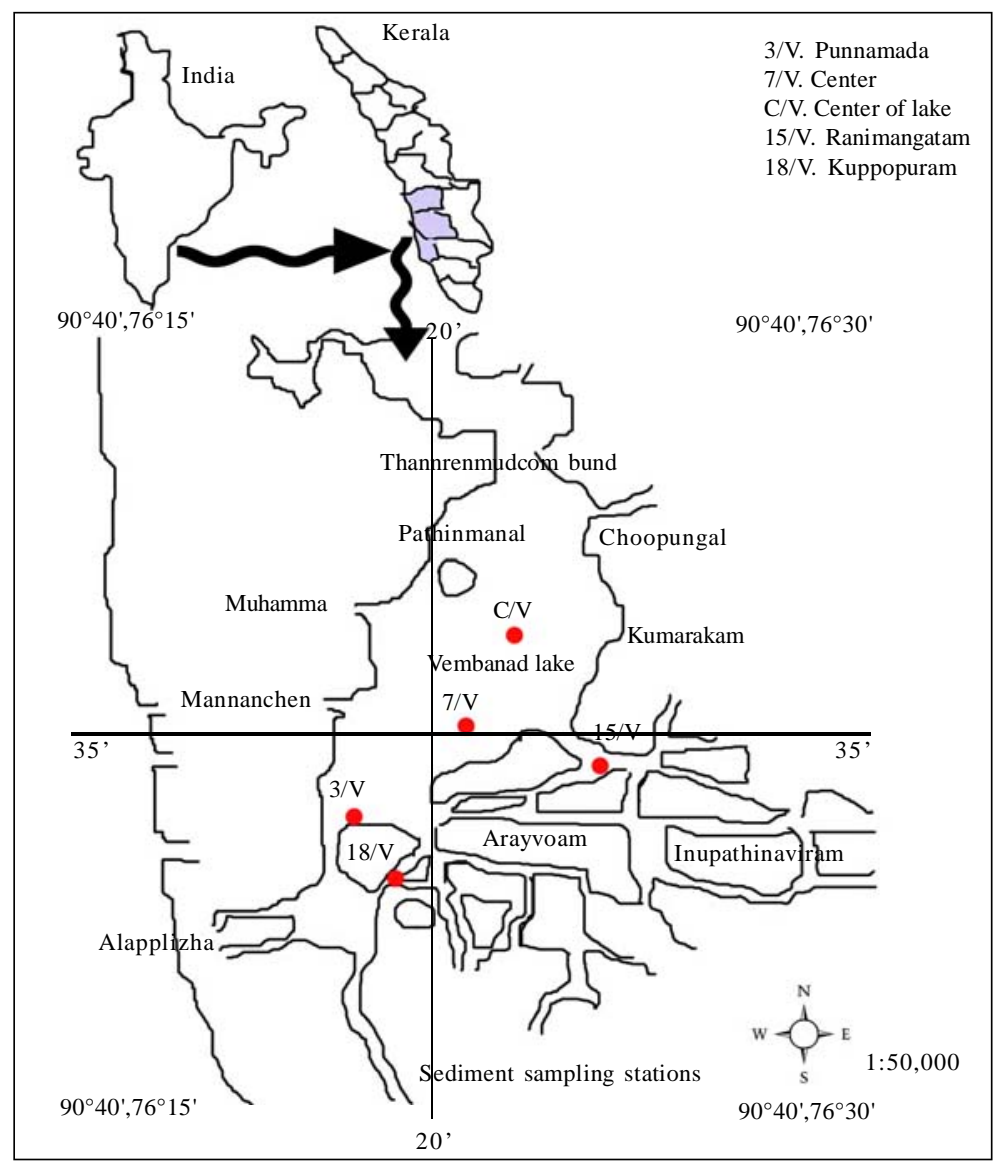

Fig. 1: Fresh water region of Vembanad Lake showing core sediment sampling sites

$82.37 \mathrm{~g} / \mathrm{kg}$ and the highest distribution was reported in the sample $\mathrm{C} / \mathrm{V}$ which was collected from the middle of the lake. There is an increase in the concentration from bottom to the surface of the sediment core, which confirmed the increased anthropogenic activities with time. Spatial variation of average concentration of iron is in the order $15 / \mathrm{V}<3 / \mathrm{V}<7 / \mathrm{V}<18 / \mathrm{V}<\mathrm{C} / \mathrm{V}$, all arehigher than the values reported in lakes such as Manyas (Alemdaroglu et al., 2003). The longitudinal variation is shown in Fig. 2. Concentration of manganese varied from $281.67 \mathrm{mg} / \mathrm{kg}$ to $1311.67 \mathrm{mg} / \mathrm{kg}$ and the mean value is $610.48 \mathrm{mg} / \mathrm{kg}$, which is higher than the value reported for Butak Menders and Gediz river sediments (Akay and Karapire, 2003). The order of distribution along the lake is $3 / \mathrm{V}<\mathrm{C} / \mathrm{V}<15 / \mathrm{V}<18 / \mathrm{V}<7 / \mathrm{V}$. The stations $3 / \mathrm{V}$ and $7 / \mathrm{V}$ showed an increasing trend from bottom with maximum concentration at a depth of $32 \mathrm{~cm}$ and then a decrease towards the surface slice shown in Fig. 3.
The concentration of copper with respect to the station follows the order of $7 / \mathrm{V}<15 / \mathrm{V}<3 / \mathrm{V}<\mathrm{C} / \mathrm{V}<18 / \mathrm{V}$ and varied from $16.73 \mathrm{mg} / \mathrm{kg}$ to $56.13 \mathrm{mg} / \mathrm{kg}$ (Fig. 4). The highest deposition of copper was present in the sample $18 / \mathrm{V}$ and the concentration decreased towards the surface. All other stations showed an increasing trend towards the surface. The level of nickel with respect to stations is in the order of $7 / \mathrm{V}<3 / \mathrm{V}<15 / \mathrm{V}<\mathrm{C} / \mathrm{V}<18 / \mathrm{V}$. The concentration of nickel varied from 36.53 to 74.47 $\mathrm{mg} / \mathrm{kg}$ (Fig. 5), which is in agreement with the results of Venugopal et al. (1982). Highest concentration of zinc was observed in the top layers of the core sediments and varied from $103.39 \mathrm{mg} / \mathrm{kg}$ to $305.29 \mathrm{mg} / \mathrm{kg}$. The longitudinal variation is shown in the Fig. 6. Higher chromium was observed for the sample 18/V (4.629 $\mathrm{mg} / \mathrm{kg}$ ) and the values are in agreement with the earlier studies reported for Vembanad lake (Harikumar et al., 2007). MacDonald et al. (2000) reported a threshold 
effect concentration (TEC $=$ the concentration above which toxicity may be observed) and a probable effect concentration (PEC = the concentration above which toxicity is frequently observed) of approximately 43 and $111 \mathrm{mg} / \mathrm{kg}$ of chromium for total sediment. The source of chromium includes industrial and municipal effluents. The effluent from chromium plating industries is one of the major sources of lead. Lead concentration varied from $0.61 \mathrm{mg} / \mathrm{kg}$ to $80.03 \mathrm{mg} / \mathrm{kg}$, in the core sediment samples, which is shown in Fig. 7. The values are close to concentration of lead reported in the coastal region of Visakhapatnam (Satyanarayana et al., 1994). Most of the samples have concentration less than the EPA criteria for heavily polluted sediments $>60 \mathrm{mg} / \mathrm{kg}$ (Alemdaroglu et al., 2003). The concentration of cadmium had varied from $0.07 \mathrm{mg} / \mathrm{kg}$ to $2 \mathrm{mg} / \mathrm{kg}$ and uniformly distributed without any trend (Fig. 8). The highest concentration of mercury reported was $1.6 \mathrm{mg} / \mathrm{kg}$ and the variation of $\mathrm{Hg}$ vertically is shown in Fig. 9.

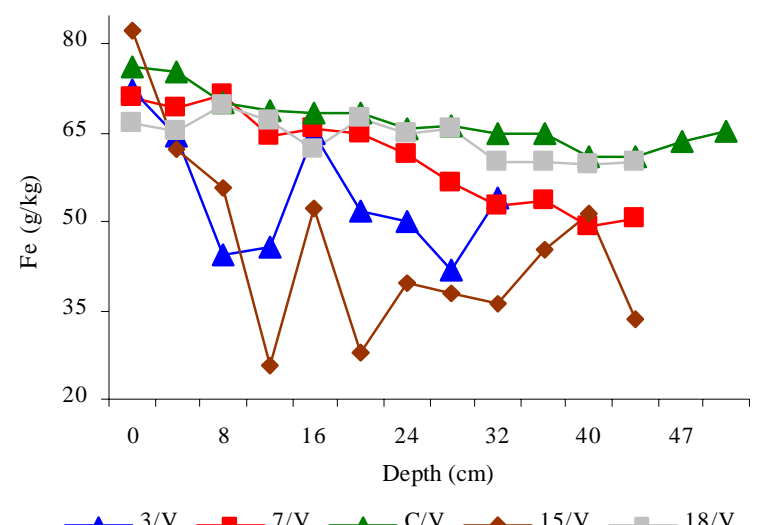

Fig. 2: Down core variation of $\mathrm{Fe}$ in the sediment cores

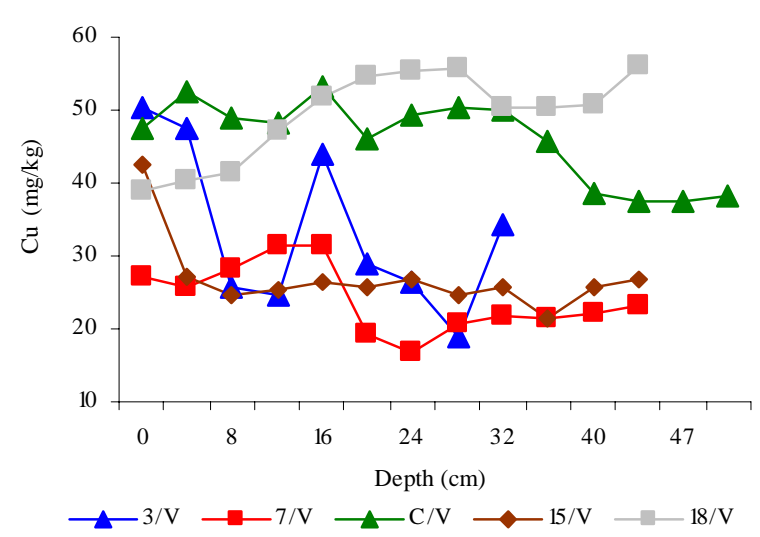

Fig. 4: Distribution of $\mathrm{Cu}$ in sediment cores
Assessment of sediment pollution using different indices sediment contamination by comparison with effect based sediment quality guideline (SQG)

Numerical sediment quality guidelines (SQGs) have been used to identify contaminants of concern in aquatic ecosystem (MacDonald et al., 2000). Sediments were classified as non-polluted, moderately polluted and heavily polluted, based on SQG of USEPA (Perin et al., 1997). Average concentration of heavy metals in the core sediments are summarized in Table 2 . In the present study crustal abundance was used as reference lines (Taylor 1972). From the table it is found that the sediments in Vembanad Lake were polluted in moderate rate for copper, moderate to heavy rate for zinc and nickel and non polluted to moderate rate for lead.

Assessment of sediment contamination by comparison of concentration with those of background sediments Hakanson et al. (1980) had suggested a contamination

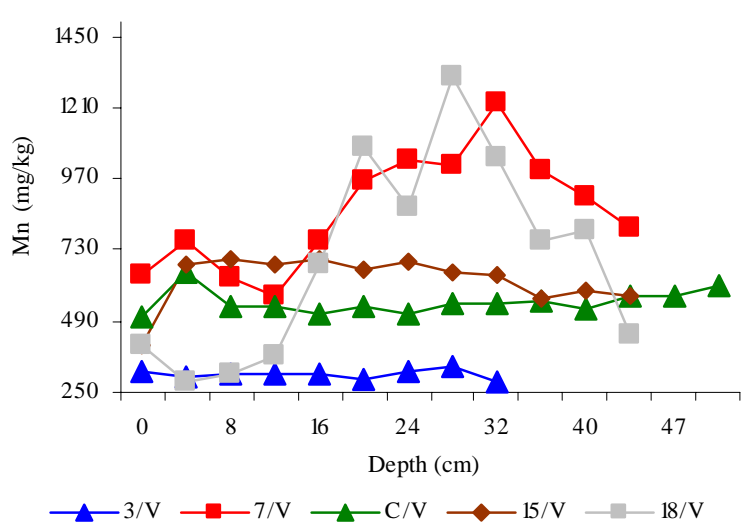

Fig. 3: Down core variation of $\mathrm{Mn}$ in the sediment cores

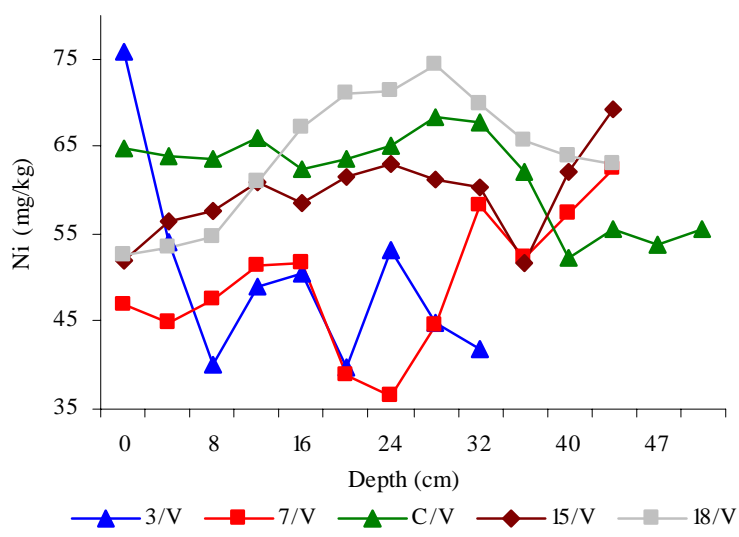

Fig. 5: Distribution of $\mathrm{Ni}$ in sediment cores 


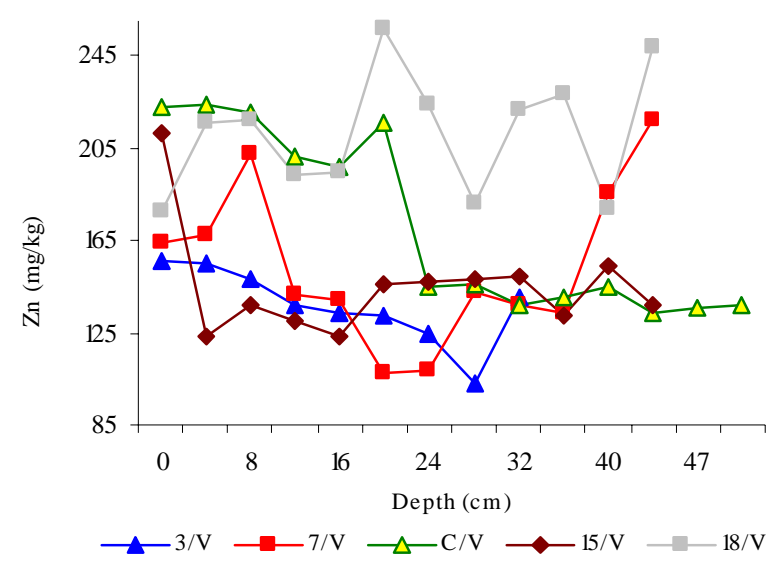

Fig. 6: Down core variation of $\mathrm{Zn}$ in the sediment core

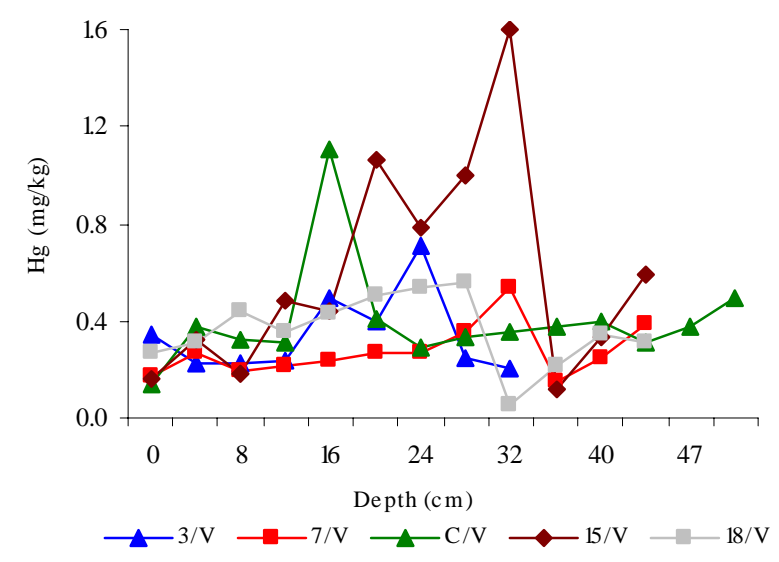

Fig. 8: Depth wise distribution of Cd along the sediment cores

factor $\left(\mathrm{C}_{\mathrm{f}}^{\mathrm{i}}\right)$ and the degree of contamination $\left(\mathrm{C}_{\mathrm{d}}\right)$ to describe the contamination of given toxic substance given by $\mathrm{C}_{\mathrm{f}}^{\mathrm{i}}=\mathrm{C}_{0-1}^{\mathrm{i}} / \mathrm{C}_{\mathrm{n}}^{\mathrm{i}}$ and $\mathrm{Cd}=\sum_{\mathrm{i}=1}^{7} \mathrm{C}_{\mathrm{f}}^{\mathrm{i}}$

Where, $\mathrm{C}_{0-1}^{\mathrm{i}}$ is the mean content of the substance; $\mathrm{C}_{\mathrm{n}}^{\mathrm{i}}$ is the reference value for the substance.

The terminologies in Table 1 are used to describe the contamination factor. The contamination factor for the sediment samples are given in the Table 3 . All the stations except $15 / \mathrm{V}$ indicate moderate degree of contamination. The station $15 / \mathrm{V}$ had low degree of contamination.

Table 1: The terminologies used to describe the contamination factor

\begin{tabular}{rrl}
\hline \multicolumn{1}{c}{$\mathrm{C}_{\mathrm{f}}^{\mathrm{i}}$} & \multicolumn{1}{c}{$\mathrm{C}_{\mathrm{d}}$} & Description \\
\hline $\mathrm{C}_{\mathrm{f}}^{\mathrm{i}}<1$ & $\mathrm{C}_{\mathrm{d}}<7$ & low degree of contamination \\
$1<\mathrm{C}_{\mathrm{f}}^{\mathrm{i}}<3$ & $7<\mathrm{C}_{\mathrm{d}}<14$ & moderate degree of contamination \\
$3<\mathrm{C}_{\mathrm{i}}<6$ & $14<\mathrm{C}_{\mathrm{d}}<28$ & considerable degree of contamination \\
$\mathrm{C}_{\mathrm{f}}>6$ & $\mathrm{C}_{\mathrm{d}}>28$ & very high degree of contamination \\
\hline
\end{tabular}

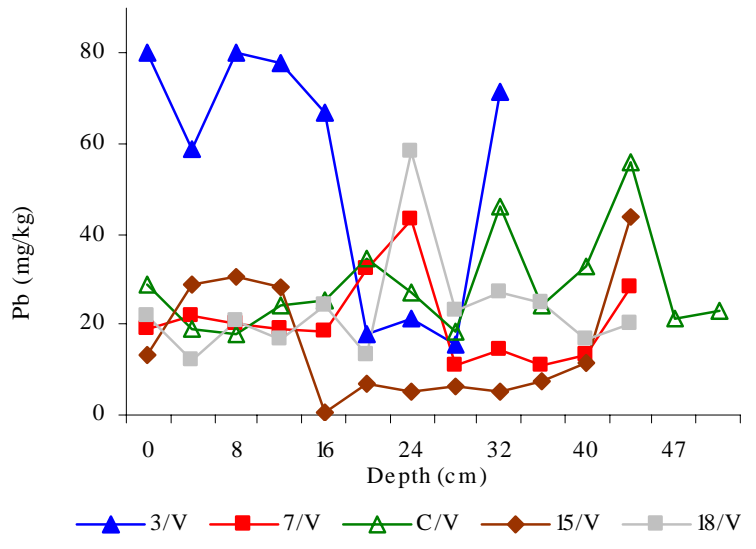

Fig. 7: Down core variation of $\mathrm{Pb}$ in the sediment core

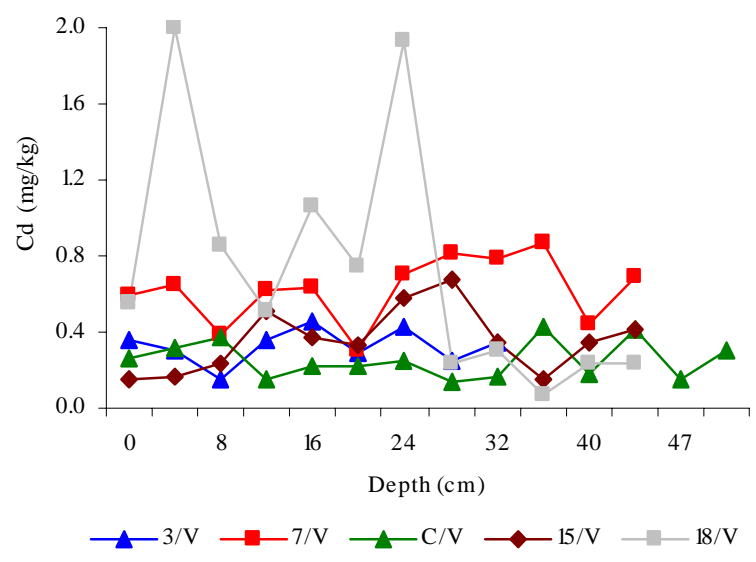

Fig. 9: Depth wise distribution of $\mathrm{Hg}$ along the sediment cores

Assessment of pollution by calculating the pollution load index (PLI)

Tomlinson et al. (1980) had employed a simple method based on pollution load index (PLI) to assess the extent of pollution by metals in estuarine sediments (Satyanarayana et al., 1994). Sediment pollution load index (PLI) was calculated using the equation PLI (product of $n$ number of CF values) $)^{1 / n}$.

Where, $\mathrm{CF}$ is the contamination factor, $\mathrm{n}$ the number of metals and world average concentration of elements reported for shale was taken as their background values. The PLI values calculated for each of the stations were summarized in Table 4 . The PLI value of $>1$ is polluted whereas $<1$ indicates no pollution. Concentration levels of $\mathrm{Pb}, \mathrm{Cd}, \mathrm{Zn}$ and $\mathrm{Fe}$ in most of the stations exceeded the world average concentration of shale (Satyanarayana et al., 1994). The station, Ranimangalam (15/V) showed less concentration than 
P. S. Harikumar et al.

Table 2: Concentration of heavy metals in the core sediment and its comparison with SQGs

\begin{tabular}{|c|c|c|c|c|c|c|c|c|c|}
\hline \multirow{2}{*}{$\begin{array}{l}\text { Element } \\
\mathrm{mg} / \mathrm{kg}\end{array}$} & \multicolumn{5}{|c|}{ Sampling stations } & \multirow{2}{*}{$\begin{array}{c}\text { Elemental } \\
\text { background } \\
\text { conc. }\end{array}$} & \multirow{2}{*}{$\begin{array}{l}\text { SQG non- } \\
\text { polluted }\end{array}$} & \multirow{2}{*}{$\begin{array}{l}\text { SQG moderate } \\
\text { polluted }\end{array}$} & \multirow{2}{*}{$\begin{array}{c}\text { SQG heavily } \\
\text { polluted }\end{array}$} \\
\hline & $3 / \mathrm{V}$ & 7/V & $\mathrm{C} / \mathrm{V}$ & $15 / \mathrm{V}$ & $18 / \mathrm{V}$ & & & & \\
\hline $\mathrm{Cu}$ & 33.43 & 24.08 & 46.43 & 26.93 & 49.43 & 55.0 & $<25$ & $25-50$ & $>50$ \\
\hline $\mathrm{Zn}$ & 136.5 & 153.7 & 181.8 & 144.8 & 211.3 & 70.0 & $<90$ & $90-200$ & $>200$ \\
\hline $\mathrm{Mn}$ & 310.0 & 860.9 & 553.9 & 630.9 & 696.3 & 950.0 & - & - & - \\
\hline $\mathrm{Cr}$ & 1.79 & 2.04 & 2.18 & 2.01 & 2.36 & 100.0 & $<25$ & $25-75$ & $>75$ \\
\hline $\mathrm{Cd}$ & 0.33 & 0.63 & 0.26 & 0.36 & 0.73 & 0.2 & - & - & - \\
\hline $\mathrm{Pb}$ & 54.42 & 21.03 & 52.51 & 15.65 & 23.22 & 12.5 & $<40$ & $40-60$ & $>60$ \\
\hline $\mathrm{Ni}$ & 49.92 & 49.37 & 62.04 & 59.61 & 64.02 & 75.0 & $<20$ & $20-50$ & $>50$ \\
\hline
\end{tabular}

Table 3: Contamination factor and degree of contamination of Vembanad Lake sediments

\begin{tabular}{|c|c|c|c|c|c|c|c|}
\hline $\begin{array}{c}\text { Sampling station } \\
\text { ID }\end{array}$ & \multicolumn{6}{|c|}{$\mathrm{C}_{\mathrm{f}}^{\mathrm{i}}$ for different metals } & $\mathrm{C}_{\mathrm{d}}$ \\
\hline $7 / \mathrm{V}$ & 0.44 & 2.20 & 0.02 & 3.13 & 1.68 & 0.66 & 7.47 \\
\hline $15 / \mathrm{V}$ & 0.49 & 2.07 & 0.02 & 1.78 & 1.25 & 0.79 & 5.61 \\
\hline $18 / \mathrm{V}$ & 0.90 & 3.02 & 0.02 & 3.64 & 1.86 & 0.85 & 9.44 \\
\hline Reference & 1.00 & 1.00 & 1.00 & 1.00 & 1.00 & 1.00 & 6.00 \\
\hline
\end{tabular}

Table 4: Heavy metal comparison with average shale value and the pollution load index

\begin{tabular}{|c|c|c|c|c|c|c|c|c|}
\hline \multirow{2}{*}{ Sampling stations } & \multicolumn{7}{|c|}{ Heavy metal (mg/kg) (Fe in g/kg) } & \multirow[b]{2}{*}{ PLI } \\
\hline & $\mathrm{Cu}$ & $\mathrm{Pb}$ & $\mathrm{Cd}$ & $\mathrm{Zn}$ & Mn & $\mathrm{Fe}$ & $\mathrm{Ni}$ & \\
\hline $3 / \mathrm{V}$ & 33.43 & 54.42 & 0.33 & 136.55 & 310.09 & 54.39 & 49.92 & 0.99 \\
\hline $7 / \mathrm{V}$ & 24.08 & 21.03 & 0.63 & 153.71 & 860.97 & 60.94 & 49.37 & 1.11 \\
\hline $15 / \mathrm{V}$ & 26.93 & 15.65 & 0.36 & 144.83 & 630.98 & 45.88 & 59.61 & 0.87 \\
\hline $18 / \mathrm{V}$ & 49.43 & 23.22 & 0.73 & 211.39 & 696.39 & 64.13 & 64.02 & 1.47 \\
\hline Average shale & 45 & 20 & 0.3 & 95 & 900 & 46.7 & 68 & \\
\hline
\end{tabular}

the shale value except the elements $\mathrm{Cr}$ and $\mathrm{Zn}$. The PLI values showed a high pollution load at stations Kuppapuram (18/V) and in the centre of the lake (C/V).

Ecotoxicological sense of heavy metal contamination

The ecotoxicological sense of heavy metal contamination in sediments was determined using sediment quality guidelines developed for marine and estuarine ecosystem (Bakan and Ozkoc, 2007). These effects are as follow:

a) The effect range low (ERL) / effect range median (ERM)

b) The threshold effect level (TEL) / probable effect level (PEL)

Where, ERL and TEL are concentrations below which adverse effects upon sediment dwelling fauna would infrequently be expected whereas, ERM and PEL represent chemical concentration above which adverse effects are likely to occur. From the Table 5, it is found that except nickel all other elements are at low to moderate range according to TEL and PEL values. For nickel, the stations C/V (centre of the lake), 15/V (Ranimangalam) and 18/V (Kuppapuram) exceeded the ERM levels. The potential acute toxicity of contaminants in sediment sample can be estimated as the sum of the toxic units (TU) defined as the ratio of the determined concentration to PEL value (Pederson et al., 1998). From the toxic unit values, the stations 18/V (Kuppapuram) and C/V (centre of the lake) are more polluted compared to others.

Comparison with some earlier studies on different rivers A comparison of metal concentration with different values reported for different rivers is generally taken as the quick and practical method for tracing heavy metal enrichment. The average values of the metal concentrations reported by other workers on some of the important rivers (Jain, 2004) have been summarized in Table 6. The comparison study with different rivers revealed that the average metal load of Vembanad lake is quit higher in the sediments.

\section{CONCLUSION}

The study of distribution of heavy metal along the core sediments of Vembanad Lake demonstrates that, 
Int. J. Environ. Sci. Tech., 6 (2), 225-232, Spring 2009

Table 5: Sum of the toxic units (TU) of core sediments and various guidelines for heavy metals

\begin{tabular}{|c|c|c|c|c|c|c|c|c|c|}
\hline \multirow{2}{*}{$\begin{array}{l}\text { Element, } \\
\mathrm{mg} / \mathrm{kg}\end{array}$} & \multicolumn{5}{|c|}{ Sampling stations } & \multirow{2}{*}{ TEL } & \multirow{2}{*}{ PEL } & \multirow{2}{*}{ ERL } & \multirow{2}{*}{ ERM } \\
\hline & $3 / \mathrm{V}$ & $7 / \mathrm{V}$ & $\mathrm{C} / \mathrm{V}$ & $15 / \mathrm{V}$ & $18 / \mathrm{V}$ & & & & \\
\hline $\mathrm{Cu}$ & 33.43 & 24.08 & 46.43 & 26.93 & 49.43 & 18.70 & 110.00 & 34.00 & 270.00 \\
\hline $\mathrm{Zn}$ & 136.55 & 153.71 & 181.80 & 144.83 & 211.39 & 124.00 & 270.00 & 150.00 & 410.00 \\
\hline $\mathrm{Cd}$ & 0.33 & 0.63 & 0.26 & 0.36 & 0.73 & 0.68 & 4.20 & 1.20 & 9.60 \\
\hline $\mathrm{Pb}$ & 54.42 & 21.03 & 52.51 & 15.65 & 23.22 & 30.20 & 110.00 & 46.70 & 218.00 \\
\hline $\mathrm{Ni}$ & 49.92 & 49.37 & 62.04 & 59.61 & 64.02 & 15.90 & 43.00 & 20.90 & 51.60 \\
\hline
\end{tabular}

Table 6: Comparison of heavy metal concentration with some rivers

\begin{tabular}{|c|c|c|c|c|c|c|c|c|c|}
\hline \multirow{2}{*}{ Rivers } & \multicolumn{4}{|c|}{ Heavy metal (mg/kg) } & & \multicolumn{4}{|c|}{ Heavy metal (mg/kg) } \\
\hline & $\mathrm{Cu}$ & $\mathrm{Pb}$ & $\mathrm{Cd}$, & $\mathrm{Zn}$ & Rivers & $\mathrm{Cu}$ & $\mathrm{Pb}$ & $\mathrm{Cd}$ & $\mathrm{Zn}$ \\
\hline Ganga & 10.8 & 25.6 & 2.55 & 36.1 & Illinois, USA & 19 & 28 & 2 & 81 \\
\hline Ganga & 21 & 25 & - & 46 & Yamuna & 52 & 57 & - & 123 \\
\hline Brahmaputhra & 17 & - & & 47 & Yamuna & 22.2 & 60 & 9.5 & 59.2 \\
\hline Genesse, USA & 18 & 40 & - & 69 & Average shale & 45 & 20 & 0.3 & 95 \\
\hline Toyohira, Japan & 22 & 24 & 0.2 & 152 & Vembanad & 36.06 & 33.37 & 0.46 & 165.66 \\
\hline Average shale & 45 & 20 & 0.3 & 95 & & & & & \\
\hline
\end{tabular}

the lake is facing heavy metal pollution. It is found that the deposition rate of heavy metals in the lake increases with time. The various heavy metals follow the order of $\mathrm{Hg}<\mathrm{Cd}<\mathrm{Cr}<\mathrm{Pd}<\mathrm{Cu}<\mathrm{Ni}<\mathrm{Zn}<\mathrm{Mn}<\mathrm{Fe}$. Sediments in Vembanad Lake were polluted in moderate rate for copper, moderate to high rate for zinc and nickel and non polluted to moderate rate for lead according to sediment quality guideline. All the stations except Ranimangalam (15/V) indicated moderate degree of contamination. The PLI values and the toxic unit showed a high pollution load at station Kuppapuram (18/V) and in the centre of the lake (C/V). Except the element nickel, all other elements were reported low to moderate range according to threshold effect level and probable effect level values. At the centre of the lake $(\mathrm{C} / \mathrm{V})$ and at the stations Ranimangalam (15/V) and Kuppapuram (18/V), the concentration of nickel exceeded the effect range median levels. Except copper and manganese, the concentration of all the heavy metals exceeded the average shale value. The above results confirmed that the Vembanad Lake is facing serious environmental pollution especially due to heavy metals with increased rate of deposition with time. However, the contamination of the environment due to heavy metals can be confirmed by studying the chemical forms of different metals present in the sediment. Hence, the chemical partitioning will be incorporated in the future studies. The major source for the metal contamination is the industrial effluents near Cochin. The increased monsoonal supply of materials together with previously deposited sediments through the Cochin backwaters is the reason for this increased metal contamination.

\section{ACKNOWLEDGEMENTS}

The authors wish to express their gratitude to the Department of Science and Technology (DST), Government of India for the financial assistance to carryout the research work.

\section{REFERENCES}

Akay, H. A.; Karapire, C. O., (2003). Study of heavy metal pollution and speciation in Butak menders and Gediz river sediments. Water Res., 37 (3), 813-822 (10 pages).

Alemdaroglu, T.; Onur, E.; Erkakan, F., (2003). Trace metal levels in surface sediments of lake Manyas, Turkey and tributary rivers. Int. J. Environ. Stud., 60 (3), 287-298 (12 pages).

Al-Masri, M. S.; Aba, A.; Khalil, H.; Al-Hares, Z., (2002). Sedimentation rates and pollution history of a dried lake: Al-Qteibeh Lake., Sci. Total Environ., 293 (1-3), 177-189 (13 pages).

Bakan, G.; Ozkoc. H. B., (2007). An ecological risk assessment of the impact of heavy metals in surface sediments on biota from the mid-Black Sea coast of Turkey. Int. J. Environ. Stud., 64 (1), 45-57 (13 pages).

Balachandran, K. K.; Joseph, T.; Nair, K. K. C.; Nair, M.; Joseph, P. S., (2002). The complex estuarine formation of six rivers (Cochin backwaters system on west coast of India)Sources and distribution of trace metals and nutrients. APN/ SASCOM/LOICZ regional workshop on assessment of material fluxes to the coastal zone in South Asia and their Impacts. Negombo, 8-11 December. Sri Lanka.

Balachandran, K. K.; Joseph, T.; Nair, M.; Sankaranarayanan, V. N.; Das, V. K.; Sheeba, P., (2003). Geochemistry of surficial sediments along the central southwest coast of India-seasonal changes in regional distribution. J. Coast. Res., 19 (3), 664683 (20 pages).

Bellucci, L. G.; El Moumni, B.; Collavini, F.; Frignani, M.; Albertazzi, S., (2003). Heavy metals in Morocco Lagoon and river sediments. J. Phys., 107 (1), 139-142 (4 pages).

Bertolotto, R. M.; Tortarolo, B.; Frignani, M.; Bellucci, L. G.; Albanese, S.; Cuneo, C., (2003). Heavy metals in coastal 
sediments of the Ligurian sea off Vado Ligure. J. Phys., 107 (1), 159-162 (4 pages).

Bonnevie, N. L.; Huntley, S. L.; Found, B. W.; Wenning, R. J., (1994). Trace metal contamination in surface sediments from Newark Bay, New Jersey. Sci. Total Environ. 144 (1), 1-16 (16 pages).

Borretzen, P.; Salbu, B., (2002). Fixation of Cs to marine sediments estimated by a stochastic modeling approach. J. Environ. Radio., 61 (1), 1-20 (20 pages).

Cohen, A. S., (2003). Paliolimnology, Oxford University Press, New York.

Hakanson, L., (1980). Ecological risk index for aquatic pollution control. A sedimentological approach. Water Res., 14 (5), 975-1001 (26 pages).

Harikumar, P. S.; Madhavan, K.; Shimjidha, P.; Bindu, K. R.; (2007). Study on hydrochemistry and sediment quality of Vembanad Lake in the southwest (Kerala) coast of India. Eco-chronicle., 2 (2), 69-80 (12 pages).

Heyvaert, A. C.; Reuter, J. E.; Sloton, D. G.; Goldman, C. R., (2000). Paleo-limnological reconstruction of historical atmospheric lead and mercury deposition at Lake Tahoe. California-Nevada. Environ. Sci. Tech., 34 (17), 3588-3597 (10 pages)

Jain, C. K., (2004). Metal fractionation study on bed sediments of River Yamuna, India. Water Res., 38 (3), 569-578 (10).

Karbassi, A. R.; Nabi-Bidhendi, G. R.; Bayati, I., (2005). Environmental geochemistry of heavy metals in a sediment core off Bushehr, Persian Gulf. Iran. J. Environ. Health. Sci. Eng., 2 (4), 255-260 (6 pages).

Lee, S. V.; Cundy, A. B., (2001). Heavy metal contamination and mixing process $\mathrm{s}$ in sediments from the Humber estuary, Eastern England. Estuaries Coast. Shelf Sci., 53 (5), 619-636 (18 pages)

Lopez, P.; Lluch, X., (2000). Sediment geochemistry of a meromictic coastal lagoon, ESCIBOLLAR(MAJORCA, SPAIN). Limnetica, 18, 15-27 (13 pages).

MacDonald, D. D.; Ingersoll, C. G.; Berger, T. A., (2000). Development and evaluation of consensus-based sediment quality guidelines for freshwater ecosystems. Arch. Environ. Contam. Toxicol., 39, 20-31 (12 pages).

Mohamed, A. W., (2005). Geochemistry and sedimentology of core sediments and the influence of human activities, Qusier, Safaga and Hasighada Harbors, Red sea coast, Egypt. Egyptian J. Aquatic Res., 31 (1), 92-103 (12 pages).

Mudholkar, A. V.; Pattan, J. N.; Parthiban, G., (1993). Geochemistry of deep sea sediment cores from the Central Ocean Basin. Indian J. Mar. Sci., 22, 241-246 (6 pages).

Ouseph, P. P., (1987). Heavy metal pollution in the sediments of Cochin estuarine system. National seminar on estuarine management, 123-127.

Pederson, F.; Bjorestad, E.; Anderson, H. V.; Kjolholt, J.; Poll, C., (1998). Characterization of sediments from Copenhagen Harbour by use of biotests. Water Sci. Tech., 37 (6-7), 233240 (8 pages).

Perin, G.; Bonardi, M.; Fabris, R.; Simoncini, B.; Manente, S.; Tosi, L.; Scotto, S., (1997). Heavy metal pollution in central Venice Lagoon bottom sediments: evaluation of the metal bioavailability by geochemical speciation procedure. Environ. Tech., 18, 593-604 (12 pages).

Pillai, V. K.; Valsala, K. K., (1995). Seasonal variation of some metals in bivalve mollusk Sunetta scripta from the Cochin coastal waters. Indian J. Mar. Sci., 24 (2), 113-115 (3 pages).

Sadiq, M., (1992). Toxic metal chemistry in marine environments. 237-241.

Sankaranarayanan, V. N.; Jayalakshmy, K. V.; Tresiamma J., (1998). Particulate trace metals in Cochin backwaters: distribution of seasonal indices. Indian J. Fish., 45 (3), 321329 (9 pages).

Satyanarayana, D.; Panigrahy, P. K.; Sahu, S. D., (1994). Metal pollution in harbor and coastal sediments of Visakhapatnam, east coast of India. Indian J. Mar. Sci., 23 (1), 52-54 (3 pages).

Taylor, S. R., (1972). Abundance of chemical elements in the continental crust: a new table. Geochim. Cosmochim. Acta., 28 (8), 1273-1285 (13 pages).

Tomlinson, D. C.; Wilson, J, G.; Harris, C. R.; Jeffery, D. W., (1980). Problems in the assessment of heavy metals levels in estuaries and the formation of a pollution index. Helgol. Wiss. Meeresunters, 33 (1-4), 566-575 (10 pages).

UNEP, (1985). Reference methods for marine pollution studies, United Nations Environment Program. Regional seas., 31-39.

Unnikrishnan, P.; Nair, S. M., (2004). Partitioning of trace metals between dissolved and particulate phases in a typical backwater system of Kerala, India., Int. J. Environ. Studies., 61 (6), 659-676 (18 pages).

USEPA, (1999). SW-846.,Reference methodology. Standard opening procedure for the digestion of soil/sediment sample using a hot plate/beaker digestion technique, Chicago, IL.

Venugopal, P.; Sarala Devi, K.; Remani, K. N.; Unnithan, R. V., (1982). Trace metal levels in sediments of the Cochin backwaters. Mahasagar, 15 (4), 205-214 (10 pages).

Weis, D. A.; Callaway, J. C.; Gersberg, R. M., (2001). Vertical accretion rates and heavy metal chronologies in wetland sediments of the Tijuana Estuary. Estuaries, 24 (6A), 840850 (11 pages).

\section{AUTHOR (S) BIOSKETCHES}

Harikumar, P. S., Ph.D., Scientist and incharge, Central Water Analysis Laboratory, Centre for Water Resources Development and Management (CWRDM), Kozhikode-673571, Kerala, India. Email: drpshari@yahoo.co.in

Nasir, U. P., M.Sc. M.Phil. in Chemistry, Senior research fellow, Central Water Analysis Laboratory, Centre for Water Resources Development and Management (CWRDM), Kozhikode-673571, Kerala, India. Email: nasirchemistry@yahoo.com

Mujeebu Rahman, M. P., M.Sc. in Chemistry, Junior research fellow, Central Water Analysis Laboratory, Centre for Water Resources Development and Management (CWRDM), Kozhikode-673571, Kerala, India. Email: mujeeburahman_mp@yahoo.co.in 